\title{
Preparasi Membran Selulosa Asetat untuk Penyaringan Nira Tebu
}

\author{
Sri Wahyu Murni dan Sri Sudarmi \\ Prodi Teknik Kimia FTI UPN "Veteran" Yogyakarta \\ Jl. SWK 104 (Lingkar Utara), Condong Catur, Yogyakarta - 55283 \\ Telp/Fax: +62274-486889, \\ Email:wahyuswm@yahoo.com
}

\begin{abstract}
Abstrak
Pada proses pembuatan gula saat ini, nira tebu dimurnikan secara fisika dan kimia yang memerlukan energi tinggi dan menghasilkan limbah. Proses pemisahan dengan membran merupakan alternatif untuk mengatasi masalah tersebut. Pada penelitian ini dibuat membran dari bahan selulosa asetat dengan metode inversi fasa dan aseton sebagai pelarut serta aditif formamida. Percobaan dilakukan dengan memvariasikan konsentrasi selulosa asetat dan waktu penguapan. Selulosa aseatat,aseton dan formamida dengan komposisi tertentu diaduk selama 3-4 jam sampai homogen. Campuran kemudian dimasukkan ke dalam botol dan ditutup rapat dan dibiarkan selama 1 hari. Selanjutnya dituang pada cetakan kaca datar dan diuapkan selama waktu yang telah ditentukan. Cetakan beserta lapisan membran dimasukkan dalam bak berisi air pada suu $2^{\circ} \mathrm{C}$ selama 5 menit, membran yang terbentuk kemudian dikeringkan. Membran yang diperoleh diuji kinerjanya menggunakan larutan nira tebu. Dari hasil percobaan diperoleh kondisi yang relatif baik yaitu pada komposisi (\% berat) selulosa asetat : aseton : formamida (12,5:52,5:35) dan waktu penguapan 45 detik; membran memiliki fluks $6,16981 / \mathrm{m}^{2}$.jam, rejeksi terhadap TSS $91,12 \%$ dan permeasi terhadap sukrosa $89 \%$.
\end{abstract}

Kata kunci: membran selulosa asetat, nira tebu, rejeksi, permeasi

\begin{abstract}
In the current the sugar cane process, the liquid sugar cane is purified by physical and chemical processes that need much energy and produce waste. Membrane process separation is alternative way for purifying it. In this research, membrane was prepared from cellulose acetate by phase inversion method with acetone as a solvent and formamide as additive. The experiment was conducted by varying cellulose acetate concentration and evaporation period. Cellulose aseatat, acetone and formamide with a particular composition is stirred for 3-4 hours until homogeneous. Mixture is then filled into the bottle and closed tightly and left for 1 day. Furthermore, the mold is poured on flat glass and evaporated during the allotted time. Matter and its lining membrane is inserted in a tub filled with water at a temperature $2^{\circ} \mathrm{C}$ for 5 minutes, the membrane was then dried.. Performance of membrane produced was tested determination by liquid sugar cane. The result of the experiment showed that the best weight ratio of cellulose acetate:acetone:formamide was and evaporation period were 12.5:5.2:3.5 and 45 second respectively; the membrane produced have volumetric flux, rejection of TSS and permeation of sucrose were
\end{abstract} $6.16981 / \mathrm{m}^{2}$.hour, $91.12 \%$ and $89 \%$ respectively.

Keywords: cellulose acetate membrane, sugar cane, rejection, permeation.

\section{Pendahuluan.}

Pada proses pembuatan gula dari tebu, saat ini nira tebu hasil penggilingan dimurnikan dengan proses fisika dan kimia. Proses fisika meliputi dekantasi dan filtrasi, sementara proses kimia meliputi sulfitasi dan karbonatasi. Proses pemurnian ini bertujuan memisahkan komponen sukrosa dari pengotor pada nira tebu seperti serabut, zat warna, getah. Proses ini memerlukan biaya yang besar dikarenakan memerlukan energi dan bahan kimia yang mahal, disamping itu proses ini juga menghasilkan limbah yang mencemari lingkungan.
Proses pemurnian menggunakan membran ultrafiltrasi merupakan alternatif untuk memurnikan nira tebu. Membran ultrafiltrasi akan menahan pengotor di atas permukaan membran, sedangkan sukrosa dengan berat molekul (BM) rendah akan menembus pori membran. Proses ini berlangsung pada suhu lingkungan dan tidak menggunakan bahan kimia yang menghasilkan limbah yang mencemari lingkungan.

Dalam penelitian ini dilakukan pembuatan membran selulosa asetat menggunakan aditif formamida dan pelarut aseton. Variabel yang dilaksanakan adalah konsentrasi selulosa asetat dan waktu penguapan. 
Membran selulosa asetat diuji kinerjanya menggunakan larutan nira tebu.

Membran didefinisikan sebagai lapisan tipis yang bertindak sebagai batas antara dua fasa, fasa umpan (upstream) dan fasa permeat (down stream). Dalam operasi membran, aliran umpan (feed) membran dipisahkan menjadi dua aliran keluar yaitu permeat dan retentat. Permeat adalah aliran yang melewati membran, sedangkan retentat adalah aliran yang tertahan oleh membran. (Mulder, 1991)

Secara umum ada dua macam struktur membran yaitu simetrik adan asimetrik. Membran simetrik terdiri atas struktur yang seragam, ketebalan berkisar antara $10-50 \mu \mathrm{m}$ dimana semakin tipis membran maka laju permeasi akan makin meningkat. Membran asimetrik tersusun atas struktur yang tidak seragam, meliputi lapisan atas yang memiliki pori kecil dengan ketebalan 0,1-0,5 $\mu \mathrm{m}$ dan didukung lapisan berpori pada lapisan bawah dengan ketebalan 50-150 $\mu \mathrm{m}$. (Mulder, 1991)

Membran selulosa asetat merupakan membran sintetis yang dibuat dari bahan polimer selulosa asetat dengan aseton sebagai pelarut dan formamida sebagai aditif untuk membentuk membran berpori. Membran ini banyak digunakan dalam proses mikrofiltrasi dan ultrafiltrasi.

Prinsip operasi ultrafiltrasi adalah bahwa pemisahan didasarkan atas mekanisme pengayaan, dimana partikel yang mempunyai ukuran yang lebih kecil dari media penyaring atau membran akan lolos melewati membran dan disebut sebagai permeat. Membran ultrafiltrasi merupakan membran yang permeabel dan selektif yang dapat memisahkan molekul-molekul dengan ukuran diameter 10-1.000 $\mathrm{A}^{\mathrm{o}}$. Bahan-bahan yang dapat dipisahkan berupa makromolekul seperti protein, lemak dan senyawa koloid yang mempunyai kisaran berat molekul (BM) $2.000-300.000$ (Baker, 2004).

Membran selulosa asetat dapat dibuat dengan metode inversi fasa atau immersi presipitasi yaitu suatu proses dimana larutan homogen yang berisi bahan polimer, pelarut dan aditif dicetak pada glass plate, kemudian dibenamkan dalam koagulan yang berisi cairan non pelarut sehingga membentuk padatan. Membran yang terbentuk merupakan membran asimetrik. Faktor yang mempengaruhi membran yang terbentuk adalah: (1) konsentrasi polimer: konsentrasi polimer terkait dengan porositas membran, sehingga akan mempengaruhi laju alir permeat dan rejeksi (2) solven: pemilihan solven yang paling penting harus melarutkan polimer sehingga membentuk larutan homogen, (3) waktu penguapan: waktu penguapan berpengaruh pada difusi komponenkomponen dalam sistem sehingga akan berpengaruh pada morfologi membran (ukuran pori membran), waktu penguapan yang terlalu lama akan mengakibatkan membran sangat berpori sangat kecil sehingga aliran tidak dapat melewati membran; (4) bahan dan suhu koagulasi: koagulasi adalah proses pemadatan lapisan film setelah penguapan, dimana terjadi transfer massa antara solven dan non solven. ketebalan lapisan film setelah penguapan solven, (5) waktu dan suhu annealing: annealing bertujuan menurunkan kandungan air pada proses koagulasi sehingga ukuran pori makin rapat. Kenaikan suhu dan waktu annealing akan menurunkan permeabilitas dan meningkatkan rejeksi. (6) jenis dan konsentrasi aditif: aditif berfungsi meningkatkan ketidak stabilan sistem untuk mendapatkan struktur berpori pada membran.

Untuk mendapatkan membran sesuai karakteristik yang diinginkan, pengontrolan terhadap tahap pemadatan membran adalah sangat penting. Dua faktor utama yang mengontrol pembentukan membran inversi fasa adalah termodinamika dan kinetika yang saling berhubungan selama proses pemadatan larutan kasting. Pembentukan membran berhubungan dengan kesetimbangan fasa dan difusivitas diantara komponenkomponen dalam sistem. Penurunan kesetimbangan fasa dan peningkatan difusivitas mengakibatkan instantanneous demixing (pembentukan membran yang sangat cepat dalam bak non solven) dan akan menghasilkan struktur yang berpori. (Mohammadi dan Saljoughi, 2009)

\section{Metodologi.}

Selulosa asetat, aseton dan formamida $\left(\mathrm{HCONH}_{2}\right)$ diperoleh dari toko Brataco. Larutan nira tebu, diperoleh dengan cara menggiling tebu dan memerasnya.

Selulosa asetat (CA), aseton dan formamida dengan komposisi tertentu dimasukkan ke dalam labu Erlenmeyer dan diaduk selama 3-4 jam menggunakan pengaduk magnetik sampai diperoleh larutan yang homogen. Kemudian larutan tersebut dimasukkan ke dalam botol dan ditutup rapat agar tidak taerjadi penguapan, dan didiamkan selama 1 hari. Larutan kemudian dituang pada cetakan (kaca datar) dan diuapkan pada suhu kamar selama waktu yang telah ditentukan. Selanjutnya cetakan beserta lapisan yang terbentuk dimasukkan ke dalam bak berisi air pada suhu $2^{\circ} \mathrm{C}$, dibiarkan selama 5 menit agar terjadi gelatinasi dimana lapisan membran lepas dengan sendirinya dari permukaan kaca. Membran kemudian dikeluarkan dari bak koagulasi dan dibiarkan kering. Membran dipanaskan dalam air pada suhu $80^{\circ} \mathrm{C}$ selama 10 menit.

Membran yang dihasilkan diuji kinerjanya yang meliputi: fluks, rejeksi terhadap total suspended solid (TSS) dan permeasi terhadap sukrosa.

1. Rejeksi (R). Didefinisikan sebagai ukuran kemampuan suatu membran untuk menahan atau melewatkan komponen tertentu. Dalam penelitian ini rejeksi didasarkan pada kemampuan untuk menahan total suspended solid (TSS) pada larutan nira tebu.

$$
\text { rejeksi }=\frac{C_{f}-C_{p}}{C_{f}} \times 100 \%
$$


2. Fluks, didefinisikan sebagai banyaknya volume aliran per satuan luas per satuan waktu.

$$
\text { fluks }=\frac{V}{A . t}
$$

\section{Permeasi}

Dalam penelitian ini, kemampuan membran melewatkan sukrosa dinyatakan sebagai \% permeasi.

$$
\% \text { permeasi }=\frac{C_{g p}}{C_{g f}} \times 100 \%
$$

Alat uji kinerja membran disajikan pada Gambar 1.

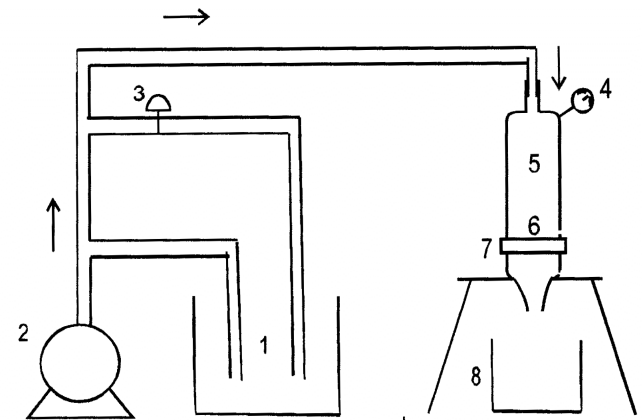

keterangan:

1. bak penampung, 2. pompa, 3. kran,

4. manometer, 5. Tabung, 6. membran,

7. penyangga membran, 8 . bak permeat

Gambar 1. Alat uji kinerja membran

Permukaan membran difoto menggunakan mikroskop polarisasi Nikon Japan 265980 dengan perbesaran 40 kali. Untuk analisis gula pereduksi dalam permeat menggunakan metode Somogyi-Nelson dapat menyatakan persentase permeasi sukrosa.
Analisis Total Suspended Solid (TSS) secara gravimetri untuk penentuan persentase rejeksi.

Proses Pembentukan membran dapat dijelaskan sebagai berikut: Pada saat kasting film mengalami imersi dalam air, pengendapan dimulai (karena kelarutan polimer (CA) dalam air sangat rendah dan ketebalan film kasting menurun dengan sangat cepat; hal ini menyebabkan kenaikan konsentrasi CA dalam film kasting. Secara bersamaan ketidaklarutan antara solven (aseton) dan non solven (air) menyebabkan beberapa hal: terjadinya aliran difusi solven dan non solven (pertukaran solven dan non solven) dan konsekuensinya adalah terbentuknya inti (nuklei) fase polimer. Akhirnya pertumbuhan nuklei berlangsung terus sampai konsentrasi polimer pada pori atau makrovoid/larutan interface menjadi sangat tinggi dan terjadilah pemadatan. Jika sistem (CA, aseton, formamida) mengalami demixing sangat cepat (instantaneus), pemadatan terjadi sangat cepatnya setelah imersi film kasting dalam bak koagulasi dan mempercepat proses presipitasi. Ini mengakibatkan peningkatan ketebalan dan porositas membran (Mohammadi dan Saljoughi, 2009).

Percepatan demixing berhubungan langsung dengan instabilitas termodinamik dan difusivitas diantara komponen di dalam komponen selama pemadatan larutan kasting. Adanya formamida sebagai aditif meningkatkan instabilitas termodinamik dan menurunkan difusivitas diantara komponen. Pengaruh penambahan formamida pada morfologi membran adalah memperbanyak terbentuknya pori membran. Gambar 4. menunjukkan, semakin sedikit komposisi CA maka permukaan memiliki pori makin besar.

\section{Hasil dan Pembahasan.}

\subsection{Pengaruh Konsentrasi Selulosa Asetat.}

$\begin{array}{ll}\text { Waktu penguapan } & : 30 \text { detik } \\ \text { Luas membran } & : 0,002026 \mathrm{~m}^{2} \\ \text { Tekanan operasi } & : 30 \mathrm{psig}=2,041 \mathrm{barg} \\ \text { Waktu fliltrasi } & : 1 \mathrm{jam}\end{array}$

Tabel 1. Pengaruh konsentrasi Selulosa Asetat terhadap fluks, Rejeksi TSS dan Permeasi Sukrosa.

\begin{tabular}{ccccccc}
\hline \multicolumn{2}{c}{ Komposisi (\% berat) } & & & $\begin{array}{c}\text { Fluks } \\
\left(1 / \mathrm{m}^{2} . \text { jam }\right)\end{array}$ & $\begin{array}{c}\text { Rejeksi (\%) } \\
\text { (terhadap TSS) }\end{array}$ & $\begin{array}{c}\text { Permeasi (\%) (terhadap } \\
\text { sukrosa) }\end{array}$ \\
\hline selulosa asetat (CA) & aseton & formamida & & 11,1067 & 81,33 & 93,07 \\
10 & 55 & 35 & & 8,5884 & 91,04 & 91,79 \\
12,5 & 52,5 & 35 & & 5,4793 & 93,70 & 75,76 \\
15 & 50 & 35 & & tak ada data & tak ada data & tak ada data \\
17,5 & 47,5 & 35 & & tak ada data & tak ada data & tak ada data \\
\hline
\end{tabular}

Data Tabel 1. memaparkan pengaruh konsentrasi selulosa asetat (CA) terhadap fluks, rejeksi TSS dan permeasi sukrosa. Semakin besar konsentrasi selulosa asetat maka fluks semakin kecil, pada konsentrasi selulosa asetat $15 \%$ fluks menurun hingga 0,5 kali dibandingkan dengan konsentrasi selulosa asetat $10 \%$ berat. Fluks berhubungan langsung dengan jumlah pori dan ukuran pori permukaan membran (top layer porosity). Kenaikan konsentrasi selulosa asetat menaikkan viskositas campuran, dan sebagai 
konsekuensinya adalah menurunkan difusivitas diantara komponen-komponen di dalam sistem selama proses solidifikasi larutan kasting, selanjutnya presipitasi berlangsung lebih lambat mengakibatkan pori membran makin kecil. Pada konsentrasi selulosa asetat yang rendah lebih banyak void terbentuk di dalam membran, sehingga meningkatkan kecepatan molekul yang melewati membran sehingga fluks lebih tinggi.

Peningkatan konsentrasi selulosa asetat meningkatkan rejeksi terhadap TSS sementara permeasi sebaliknya makin kecil. Rejeksi TSS tertinggi $(93,7 \%)$ diperoleh pada konsentrasi selulosa asetat $15 \%$ berat; penurunan jumlah solven meningkatkan rejeksi TSS. Namun demikian pada konsentrasi selulosa asetat 17,5 dan $20 \%$ berat membran tidak dapat melewatkan cairan. Semakin besar konsentrasi selulosa asetat pori membran yang tebentuk makin kecil dan rapat (Gambar 4). Hal ini menunjukkan pada kondisi tersebut membran yang diperoleh memiliki pori yang sangat kecil.

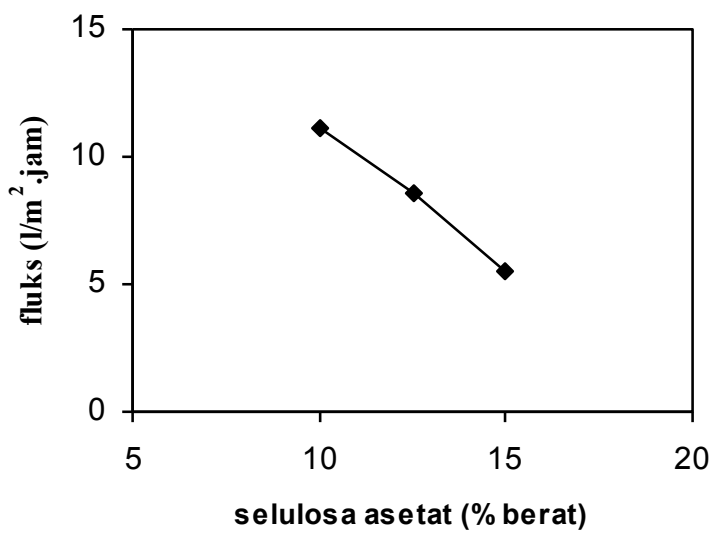

Gambar 2. Pengaruh konsentrasi selulosa asetat terhadap fluks membran

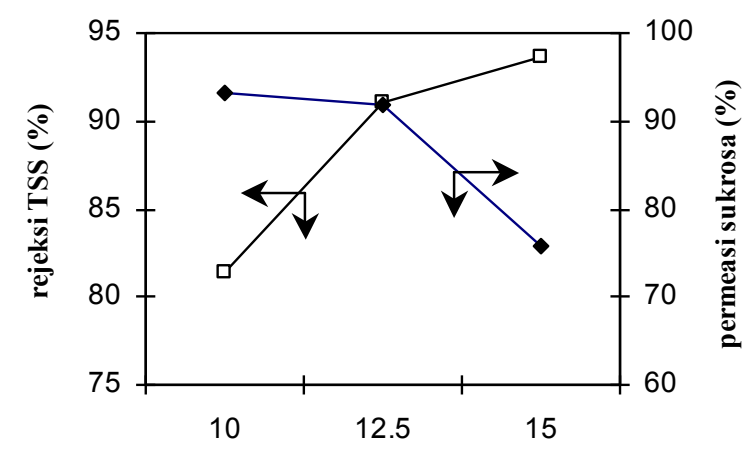

selulosa ase tat (\% berat)

Gambar 3. Pengaruh konsentrasi selulosa asetat (\% berat) terhadap rejeksi TSS dan permeasi sukrosa: $\square$, permeasi; $\diamond$, rejeksi

Gambar 4. menujukkan foto permukaan membran pada berbagai konsentrasi CA. Kenaikan konsentrasi
CA menaikkan viskositas film kasting dan konsekuesinya menurunkan difusivitas diantara komponen-komponen di dalam sistem selama proses pemadatan larutan kasting dan selanjutnya menghambat proses presipitasi dan nampak dalam gambar bahwa permukaan membran memiliki pori lebih kecil (Mohammadi dan Saljoughi, 2009).

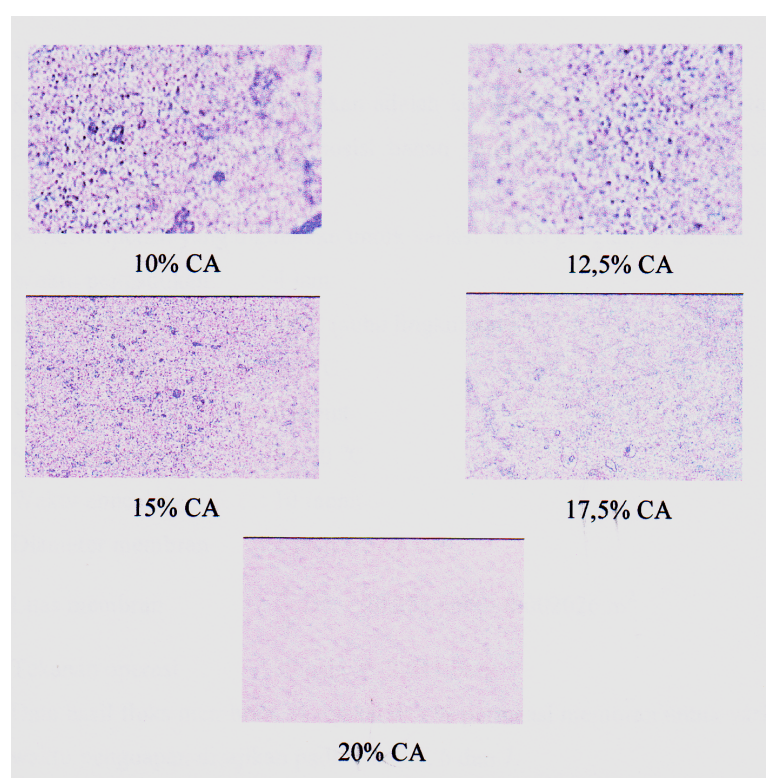

Gambar 4. Foto permukaan membran pada berbagai konsentrasi selulosa (\% berat) asetat (CA)

\subsection{Pengaruh Waktu penguapan}

$\begin{array}{ll}\text { Selulosa asetat } & : 12,5 \% \\ \text { Luas membran } & : 0,002026 \mathrm{~m}^{2} \\ \text { Tekanan operasi } & : 30 \mathrm{psig}=2,041 \mathrm{barg} \\ \text { Waktu fliltrasi } & : 1 \mathrm{jam}\end{array}$

Tabel 2. Pengaruh Waktu Penguapan terhadap Fluks, Rejeksi TSS dan Permeasi Sukrosa

\begin{tabular}{cccc}
\hline $\begin{array}{c}\text { Waktu } \\
\text { Penguapan } \\
\text { (detik) }\end{array}$ & $\begin{array}{c}\text { Fluks } \\
\left(1 / \mathrm{m}^{2} \text {.jam) }\right.\end{array}$ & $\begin{array}{c}\text { Rejeksi (\%) } \\
\text { terhadap TSS }\end{array}$ & $\begin{array}{c}\text { Permeasi (\%) } \\
\text { terhadap } \\
\text { sukrosa }\end{array}$ \\
\hline 15 & 10,86 & 90,41 & 96,32 \\
30 & 8,59 & 91,04 & 91,79 \\
45 & 6,17 & 91,12 & 89,63 \\
60 & 5,68 & 92,83 & 87,47 \\
75 & 5,43 & 94,12 & 86,39 \\
\hline
\end{tabular}

Dari data Tabel 2. diperoleh bahwa semakin lama waktu penguapan maka fluks semakin kecil, \% rejeksi terhadap TSS makin besar dan permeasi terhadap sukrosa makin kecil. Penguapan solven dari cairan membran menghasilkan suatu lapisan kulit pada permukaan. Kenaikan waktu evaporasi meningkatkan ketebalan membran, yan menyebabkan penurunan laju perpindahan. ((Zhao dkk., 2009) Semakin lama waktu penguapan, maka ukuran pori semakin kecil, karena lebih banyak molekul pelarut yang meninggalkan struktur membran. (Gambar 7) Fluks menurun dengan tajam pada rentang waktu penguapan 
15-45 detik, pada waktu penguapan 45 detik fluks hanya 0,5 kali dibandingkan dengan waktu penguapan 15 detik, setelah itu fluks cenderung konstan. Sementara rejeksi hanya sedikit mengalami peningkatan pada waktu penguapan. Permeasi sukrosa menurun cukup besar pada waktu 75 menit. Dari data tersebut di atas diperoleh kondisi yang relatif baik yaitu pada waktu penguapan 45 detik, dimana fluks tidak terlalu kecil, rejeksi TSS cukup besar sehingga pengotor nira tebu dapat dihilangkan dan permeasi terhadap sukrosa juga besar yang berarti tidak banyak sukrosa yang hilang.

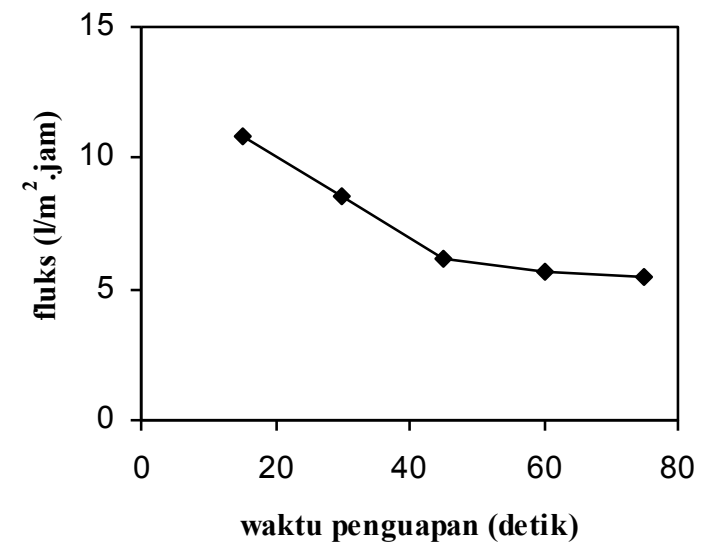

Gambar 5. Pengaruh waktu penguapan terhadap fluks membran

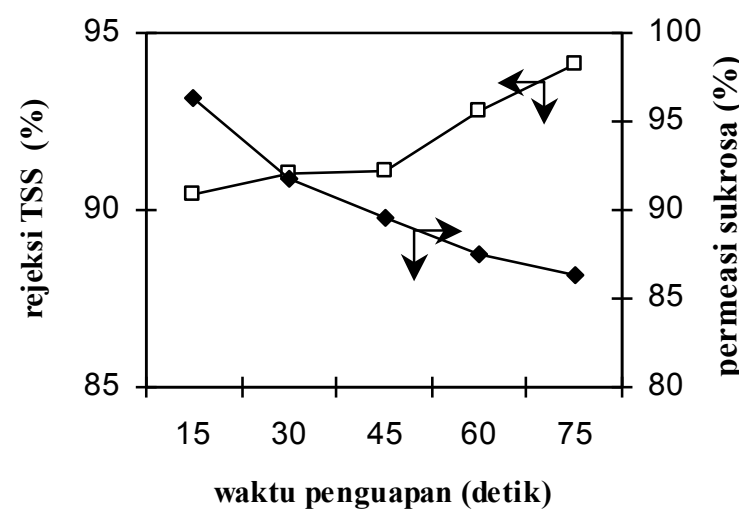

Gambar 6. Pengaruh waktu penguapan terhadap rejeksi TSS dan permeasi sukrosa: $\square$, permeasi; $\diamond$, rejeksi

Pada konsentrasi CA dan formamida yang sama dan pada suhu air bak koagulasi yang sama, tetapi pada waktu penguapan yang berbeda permukaan membran menunjukkan morfologi berbeda. (Gambar 7.) Waktu penguapan yang panjang memungkinkan difusi diantara komponen-komponen di dalam sistem selama pemadatan larutan kasting sehingga nampak dalam Gambar 7 ukuran pori permukaan makin kecil dengan semakin lamanya waktu penguapan. Sebaliknya jika waktu penguapan makin pendek maka pori membran makin besar.

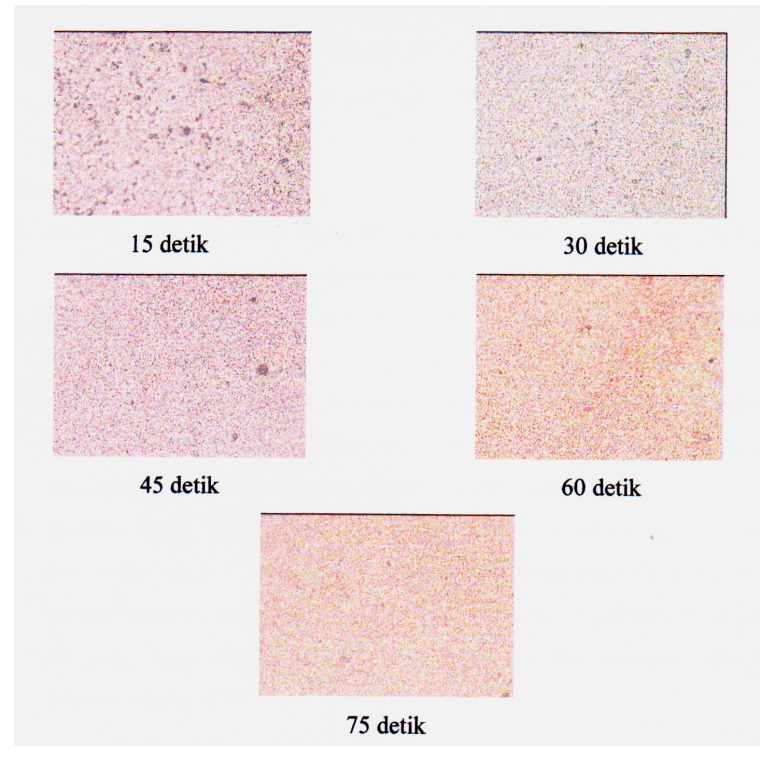

Gambar 7. Foto permukaan membran CA pada berbagai waktu penguapan

\section{Kesimpulan}

Membran selulosa asetat dapat dibuat dengan bahan dasar polimer selulosa asetat, pelarut aseton dan bahan aditif formamida. Membran selulosa asetat yang dibuat mampu melewatkan sukrosa dan merejeksi TSS. Pada komposisi (\%berat) selulosa asetat: aseton: formamida $(12,5: 52,5: 35)$ dan waktu penguapan 45 detik membran memiliki fluks $6,16981 / \mathrm{m}^{2}$.jam, rejeksi terhadap TSS $91,12 \%$ dan permeasi terhadap sukrosa $89 \%$.

\section{Ucapan terimakasih}

Ucapan terimakasih disampaikan kepada Huda Rosada dan Tri Retnani Wahyu Utami yang telah membantu dalam pengambilan data.

\section{Daftar lambang}

A : luas permukaan membran $\left(\mathrm{m}^{2}\right)$

$\mathrm{C}_{\mathrm{f}} \quad$ : konsentrasi total suspended solid (TSS) umpan (mg/l)

$\mathrm{C}_{\mathrm{gf}} \quad$ : konsentrasi gula reduksi umpan $(\mathrm{mg} / \mathrm{l})$

$\mathrm{C}_{\mathrm{gp}} \quad$ : konsentrasi gula reduksi permeat ( $\left.\mathrm{mg} / \mathrm{l}\right)$

$\mathrm{C}_{\mathrm{p}} \quad$ : konsentrasi total suspended solid (TSS) permeat (mg/l)

t $\quad$ : waktu operasi (jam)

$\mathrm{V} \quad$ : volume cairan melewati membran (1)

\section{Daftar Pustaka}

Idris, A., K.Y. Lee and H.K. King, 2005, Preparation of Cellulose Acetate Dyalisis Membrane for Separation of Bovine Serum Albumin, Jurnal Teknologi, Volume 42, Universiti Teknologi Malaysia. 
Baker, R.W., 2004, Membranne Teclnology and Applications, $2^{\text {nd }}$ edition, John Willey \& Sons Ltd, England.

Mulder, M., 1991, Basic Principles of Membranes Technology, $2^{\text {nd }}$ edition, Kluwer Academic Publishers, Nederlands.

Marlina, 2008, Pembuatan Membran Rapat Selulosa Asetat untuk Pemisahan Metanol-Metil Tersier Butil Eter dengan Pervaporasi, Master Tesis, ITB, Bandung.
Mohammadi, Toraj, Ehsan Saljoughi, 2009, Effect of production conditions on morphology and permeability of asymmetric cellulose acetate membrane, Journal of Membrane Science, 243, 1-7

Zhao, Min, Xiao-Lin Xu, Yun-Dong Jiang, Wen-Zhuo Sun, Weng-Fang Wang, Li-Ming Yuan, 2009, Enantioseparation of trans-stilbene oxide using a cellulose acetate membrane, Journal of Membrane Science, 336, 149-15 